\title{
Disintegration and Hope for Revival in the Land of the Two Rivers as Reflected in the Novels of Sinan Antoon
}

\author{
Geula Elimelekh
}

Bar-Ilan University

geula18o@gmail.com

\begin{abstract}
This article deals with three metafictional novels by the Iraqi-American writer Sinan Antoon: I'ğām (An Iraqi Rhapsody, 2004), Yā Maryam (Hail Mary, 2012), and Wahdahā šağarat al-rummān (The Pomegranate Alone, 2010), author-translated into English as The Corpse Washer (2013). The novels are set in Iraq during Șaddām Ḥusayn's dictatorship and in the aftermath of America's invasion. Antoon juxtaposes the terror of Iraqi life against characters seeking to survive through their mind-bending determination to see beauty in their fragmented world. To achieve his paradox, Antoon transports readers of his narrative's here-and-now into transcendent unrealities by using magical realism. A kind of three-dimensional dialectic operates between the natural and supernatural, and rationality and irrationality in which characters' find in their dreams respite by suspending accepted definitions of time, place, and identity. Writing in Arabic, Antoon highlights two conflicting functions of language and letters as vehicles of destruction and creativity.

Antoon's three novels, each from its own perspective, reflect his belief that although Iraq is presently in a state of disintegration, the Iraqi people are resolute in their willingness to overcome hardship and to resurrect their nation in their lifetime.
\end{abstract}

\section{Keywords}

Sinan Antoon - Iraqi literature - dictatorship - terror - magical realism 


\title{
Introduction
}

In her article "Literature and the Arts in Contemporary Iraqi Culture," Ferial J. Ghazoul points out that contemporary Iraqi art and literature describe the dismal state of the country, while also lauding the Iraqi people's will to survive and keep society and culture functioning. Not only is the tragic reality not dwelled upon but ways of enduring the traumas are proposed, for indeed every kind of artistic expression implies a desire to live and to transcend crises. She writes,

\begin{abstract}
Such creativity does not deny we have lost ground to the forces of disintegration, yet it suggests we have not lost the battle altogether. In the darkness of this existential tunnel, the cultural heroes of our time hold up candles. They neither paper over the ugly reality nor engage in political, ethnic or sectarian polarization. Instead, they offer something noble and moving. These rare cultural gifts should be treasured in these dismal and repetitive scenes of degradation. ${ }^{1}$
\end{abstract}

Ghazoul is not the only critic who characterizes the Iraqi writers as torchbearers of hope in war-torn Iraq. In her book War and Occupation in Iraqi Fiction, Ikram Masmoudi quotes author Hamzah al-Hasan, who writes in a yet unpublished manuscript titled "Hāmil Fanūs al-Nahār" [Bearer of the Torch of Day]:

The new generation of Iraqi novelists that emerged from the rubble, wars and exiles of the inside and outside ... is a promise, a prophecy and a hope. It is a promise because it has been long awaited in the country of storytelling, a prophecy because it came to us from unsuspected times ...

1 Ghazoul, Ferial J. "Literature and the Arts in Contemporary Iraqi Culture." International Journal of Contemporary Iraqi Studies, 3:3 (2009), 233-236. Ghazoul further notes that the discourse about Iraq, especially in the last few decades, has focused mainly on the country's politics and economy, whereas the arts have received little attention. However, the arts continue to be an important part of Iraqi culture and a very relevant mirror of Iraqi reality-especially since they present a different perspective from the mainstream media. These media, says Ghazoul, seek to broadcast dramatic moments and strident voices to its viewers and to reduce most situations to absolute black and white terms. Literature and the arts at the other end of the spectrum are not only "soft power" but also complex constructions and thus resist the flashiness of a TV program and the simplification of the media. However, in their indirect and sophisticated way, both are indicative of reality as well as a forecast of the future. They signify and need to be grasped in order to establish a multidimensional picture of Iraqi culture" (p. 233). 
and a hope because arrival from unsuspected directions is like a bird alighting on an isolated tree in the middle of the desert, before a lonely traveler. $^{2}$

One of the "cultural heroes" illuminating Iraq's bleak realities is Sinan Antoon on whose novels this paper focuses. Antoon is also a poet, scholar, and translator who was born in Baghdad in 1967 to an Iraqi father and American mother. His father's family belongs to Iraq's Assyrian (Chaldean) Christian minority. Antoon studied English literature at Baghdad University. He left Iraq in 1991 for the U.S., where he completed a Ph.D. in Arabic and Islamic Studies and where he resides to this day. His works describe life in Iraq during the Bat tregime and in the period following America's invasion. His books portray the brutal and unending violence, but also include many glimmers of hope that suggest that Iraq, and the world at large, may yet transcend war and build a better future. His poems and novels have been translated to nine languages.

This article examines three of Antoon's Arabic-language novels: I'ğām (An Iraqi Rhapsody, 2004), Yā Maryam (Hail Mary, 2012), and Waḥdahā šağarat alrummān (The Pomegranate Alone, 2010). In all three novels, the author depicts the nightmarish reality of his homeland, while showing ways to survive, to preserve one's sanity, and to recognize the beauty and goodness that still exists in the world.

After the downfall of the dictatorial Ba't regime, the question arose how to assess and describe the history of the Bat tera. In his paper "Conceptions and Representations of History in Modern Iraqi Fiction," Stephan Milich notes that there are two genres of historical fiction: the first typifies a form of historical realism that does not reflect on "the considerations and difficulties of representing the past"; the second deals with metafiction which approaches historiography in that it questions the ability to retell the past in a conventional, coherent, objective, and linear fashion, and instead may use multiple perspectives, disconnected streaming, and/or unreliable narrators to "scrutinize very act of writing the past itself." 3 Antoon's three novels belong to the latter genre of postcolonial, postmodernist literature, whose plot structures are non-linear and fragmented. The novels are constructed in this manner not only to explore

2 Masmoudi, Ikram. War and Occupation in Iraqi Fiction. Edinburgh, Edinburgh University Press, 2015, 17-18.

3 Milich, Stephan. "Conceptions and Representations of History in Modern Iraqi Fiction". In: From New Values to New Aesthetics: Turning Points in Modern Arabic Literature-Proceedings of the 8th EURAMAL Conference, Vol. 2: Postmodernism and Thereafter. Stephan Guth and Gail Ramsay (eds). Wiesbaden, Harrassowitz, 2011, 167-186. 
the past through flashbacks, but also to transport the reader from the book's here-and-now into otherwise unimaginable realities. This is done by using the elements of magical realism, as will be discussed below.

The novel I'g $\bar{a} m^{4}$ takes place during the Șaddām Ḥusayn era, specifically in the 1980 d during the Iran-Iraq War, and exposes the violence, oppression, coercion, degradation, and torture to which Iraqis were exposed under this brutal dictatorial regime. The novel can be said to belong to the genre of "prison literature," since it tells the story of a political prisoner.

Arabic prison literature is a subgenre of Arabic political literature; the latter deals with the socio-political aspirations and crises in the Arab world, and emerged with the recognition in Arab societies that politics plays a key role in shaping day-to-day reality. The authors of prison novels and short stories aim to expose what goes on inside the cells and torture chambers of political prisons in the Arab countries, and to bring these atrocities to the attention of the Arab public and the world at large. Often, the authors of this fiction personally experienced the horrors of political incarceration and faced formidable and sometimes even insurmountable obstacles in daring to expose this reality. ${ }^{5}$

Stephan Milich notes that imprisonment and exile are recurring themes in modern Arabic literature, especially in Iraqi and Palestinian literature, due to the political and social reality that characterize these societies. In Iraqi literature these themes are particularly dominant: prison literature reflects the dayto-day reality in the homeland, while exile literature addresses the hardships of alien life outside in foreign lands. The need to document the social and political reality in Iraq became especially acute with the rise to power of Șaddām Husayn in 1979. Many texts from the 1980s and 1990s describe the Ba'tist persecution of dissident intellectuals by the party's security apparatuses. Many of these works were written in exile by authors who had fled the country. Even after the fall of the Ba'tist regime, many Iraqi authors such as Antoon himself still reside outside Iraq, which as is well known continues to be plagued by instability and bloodshed. ${ }^{6}$

4 Antoon, Sinan. I'ğām. Beirut, Dār al-Ādāb, 2004. Quotations in this paper are from the English translation: Rebecca C. Johnson and Sinan Antoon (trans.). Ijaam: An Iraqi Rhapsody. San Francisco, City Light, 2007.

5 Elimelekh, Geula. Arabic Prison Literature: Resistance, Torture, Alienation, and Freedom. Wiesbaden, Harrassowitz, 2014, ix.

6 Milich. "Conceptions and Representations." 
One prominently discussed issue in I $I_{g} \bar{a} m$, exemplifying its genre, is the purpose of writing itself. Is it meant to satisfy a personal need of the writer, or to document reality in order to expose injustice and record it for the present generation and generations to come? Indeed, the novel begins with several epigraphs on the theme of writing. Ironically, the first quotes Șaddām Ḥusayn, "the Father-Leader":

Write without any concern or hesitation that the government may or may not be satisfied with what you write- the Father-Leader. (This quote was disseminated by the Bat $\underline{t}$ Party to create the false impression that it allows, and even encourages, freedom of speech). ${ }^{7}$

Next comes two sayings by the medieval Arab historian Ibn Hुaldūn (13321406) on the importance of writing:

As for writing, it protects man from oblivion. It transports the self to those who are distant and absent.

To write is to risk being misread or misunderstood. Words that survive their author are cut loose. They drift, take new shape, sprout new meanings. And there is always their ordinary ambiguity.

Ibn Haldūn holds that language is a means to express man's innermost soul, both his thoughts, and his emotions. This quote serves to establish Antoon's point of departure in the novel, namely that man's spiritual world-his thoughts, emotions, and ideas - is the essence of his being, however language, an external and often inadequate tool, is used to reflect that internal world. Antoon highlights two conflicting functions of language: one as a vehicle of creativity and another as a vulgar and destructive tool employed by the regime to brainwash the populace and spread its propaganda and lies.

The third epigraph is an excerpt from the classical Arabic dictionary Lisān al-Arab by Ibn Manzūr (1232-1311), presenting different meanings of the Arabic

7 Fabio Caiani and Catherine Cobham discuss the regime's methods of control in The Iraqi Novel: Key Writers, Key Texts: "From the beginning of the war against Iran in 1980, the pressure exercised by Saddam and his regime on artists and intellectuals to rally behind the war effort was considerable. Literary prizes were established for the best war poem and best work of fiction, and the regime regarded literature as an important form of propaganda [...] In fact, Iraqi writers were officially given no real choice, as is evident in the disturbing rhetoric of the following passage by Salīm 'Abd al-Qādir al-Sāmarrā'ì, [...] "Saddam had urged writers, sometimes in person, to write about his own life and the history of the Bath Party [...] However, complying with the wishes of the leader and the regime secured rewards, while non-compliance could have extreme consequences (leading in some instances to imprisonment and execution)." See Caiani, Fabio and Cobham Catherine. The Iraqi Novel: Key Writers, Key Texts. Edinburgh, Edinburgh University Press, 2013, 164-165. 
root $\langle-\dot{c} g-m\rangle$. The excerpt indicates that this root has two opposite meanings: to wit, "obscurity, vagueness," but also "to clarify [a text] by adding diacritic markings." "The word I Ǐgam (the book's title), which is derived from this root, indeed has both meanings, for it means "incoherent speech" but also "clarification by means of diacritics." This title goes to the heart of the book's message: namely, that reality as well as narrative are ambiguous and multifaceted and can be read (or misread) in many different and even contradictory ways. Through the ambiguity of the word I'ğamm, Antoon addresses multifaceted realities, whether social, cultural, or political and explores such themes as loss, identity, love, and resistance in the face of oppression. ${ }^{9}$

The book opens with an internal memo by the Directorate of General Security in the Baghdad District. Headed "classified" and dated 22 August 1989, the memo states that during a "general inventory" of the directory's files a manuscript was found written in undotted Arabic script (i.e., script without diacritical marks). The memo instructs its recipient to have a "qualified" employee read the manuscript, add the diacritical marks, and then submit a report about the manuscript's contents. The short report written by a functionary named Ṭalāl Ahmad appears at the end of the book.

The "manuscript" described in the memo is the novel itself, which is a firstperson narrative by a prisoner named Furāt. Talāl Ahmad's report at the end of the book dismisses the text as the "unrelated thoughts and illogical recollections of a prisoner." Țalāl also explains that he preserved "the frequent profanity occurring in the manuscript [...] despite the abundance of detestable images and profanity used by the writer to deride the sayings of our FatherLeader (may God preserve him), the values and achievements of the Party, and our just battle with the enemy, [because] this could help identify the writer [...]" (p. 97).

As mentioned, the writer in question is a young man named Furāt, though the novel initially leaves him unnamed, implying that his fate could befall any Iraqi citizen. ${ }^{10}$ Like Antoon himself Furāt is an Assyrian Christian. His parents died when he was a boy and he grew up in the home of his pious grandmother. guished only by their diacritical marks. Hence, a text without these marks is ambiguous and can often be read in more than one way. nation.com/ article/dot-matrix/ (accessed 7 November 2016). [Prison Literature during the Years of the Dictatorial Regime in Iraq]. London, Dār alHikmah, 2014), 248. 
Also like the author, he is a student of English literature at the University of Baghdad. In the novel's first scene, he is sitting under a palm tree on campus one morning, when he is approached by Abu 'Umar. The latter is ostensibly a student but actually a member of the secret police. Furāt notes sarcastically that Abu 'Umar transferred to the English department in the middle of the academic year after spending three years in the department of Arabic. With Abu 'Umar is another secret police officer, Salāh. The two ask Furāt to come with them "to the office" for a short while, but he knows that he is being taken to the Baghdad security complex and this knowledge fills him with fear. On the way to the complex, the car passes by the cemetery where the poet Nāzim al-Ġazālì is buried, and Furāt thinks of this poet's lyrics: "Those who threw me / those that tortured me / on a distant bridge have left me" (p. 4).

Furāt is an outspoken and fearless individual who deals with the regime's oppressive policies by mocking them, for instance, doing impressions of Șaddām Husayn. He confides to the reader that in order to retain his sanity in the face of the party's constant brainwashing, he has made a hobby of rearranging the words of the party's songs and slogans to produce provocative and comical results. Furāt also invents his own names for the government ministries, so for example the Ministry of Culture and Information becomes the Ministry of Rupture and Inflammation. He has been known to use pictures of Șaddām as toilet paper and in the elections for the student union he once put in the ballot box a vote for Mickey Mouse.

The arrest therefore comes as no surprise to Furāt. His grandmother had feared this would happen. She had begged him to be careful, warning him that if the authorities caught him they would cut out his tongue, a punishment that was sometimes meted out to dissidents. Furāt's friends Sarmad and 'Arīg had also warned him to stop mocking the regime and telling jokes about it. During the drive to the security complex, Salāh says to him sarcastically, "We have very much enjoyed your ideas. We should like to hear more about them," and Furāt wonders if someone recorded him or submitted a report about him.

On arrival at the security complex, Salāh tries cover Furāt's eyes with a blindfold and when Furāt resists Salāh knocks him out with a sharp blow. As he lies unconscious, he remembers (or perhaps dreams) an odd scene. One day he comes home to find his grandmother crying. When he asks her what the matter is, she says that a regime official said on television that citizens must donate their eyes to support the war effort. In despair the grandmother says, "They asked for money and we gave. They asked for gold and we gave. But this is just too much. May God send them all to hell! What times we are living in" (p. 6). Furāt at first refuses to believe his grandmother, until he hears the televised announcement himself. He says to himself, "How could I have forgotten 
the absurd carnival our lives have become during these last years? Everything has become possible" (p. 7). Then he picks up a newspaper and discovers to his horror that the letters of the headlines have no dots (i.e., no diacritical marks) and the faces in all the photographs have no eyes. Running outside, he discovers that the streets signs are also undotted. In front of the school that has been turned into an "eye donation center," people are laughing and cheering and some are even singing, "Everything you touched, our eyes kissed, the day you came, Oh Great Leader" (p. 7). Party officials are moving among the people, recording ages and eye color. Furāt sees 'Alī, a friend from high school and calls out to him, but 'Alì does not hear him because the sound of applause is so loud. The scene obviously draws a connection between the removal of the diacritical marks, which renders written language meaningless, and the removal of people's eyes, which renders them blind to the cruelty and injustice of the regime.

The next section in the novel begins with the line "I woke up to find myself t/here."1 This sentence with its built-in ambiguity is used several times in the book to mark the boundary between scenes. It signals a transition between different times in the story and often marks a transformation between the novel's reality and its magical-realist scenes of fantasy or dreaming. According to Milich, this sentence conveys the condition in which Furāt is concurrently in and out of prison.He adds that this blurring of boundaries is also expressed by animating or personifying the letters of the alphabet. In one of the novel's fantastical scenes, Furāt sees a door opening and letters come in. The letters play with and tease each other-until soldiers come in spray them with bullets, intimating that even the letters suffer from the regime's persecution. The letters represent language, which for the intellectual prisoner is a source of freedom and enjoyment as well as a tool of resistance and rebellion. But at the hands of the regime, language becomes a tool for subverting the truth and controlling the people. ${ }^{12}$

Waking up from his dream about the eye donations, Furāt first recalls his friend 'Alī, who also kept a journal, and appeared in the dream, saying to him, "Alì! Where are you? Did you visit me in my nightmare to encourage me to write? You used to give me your journal to read and I would labor to decipher your undotted script. To write or not to write?" (p. 8). Furāt remembers Șaddām's saying from his famous speech to the Union of Writers and Journalists (which also appears in the opening epigraphs): "Write without any concern or hesitation that the government may or may not be satisfied with what you write." Furāt's

11 In Arabic, as in English, the difference between the words 'here' (hunā) and 'there' (hunāka) is minimal. 
imprisonment obviously confirms the complete insincerity of this statement. In fact, the novel repeatedly quotes the regime's slogans in ironical contexts that starkly expose its hypocrisy. However, in prison Furāt takes the leader's advice literally and writing becomes his only mechanism of escape. He records his experiences, thoughts, memories, and dreams ("I can hear footsteps approaching my door well before the guards appear, which give me enough time to hide my papers under the mattress" p. 35) to express his opposition to the regime and also to document his plight.

After recalling 'Alī and his journal, Furāt also remembers Sarmad, his friend from the university who warned him that the authorities were onto him. When Furāt told his grandmother about Sarmad's caution, she "doubled her usual dose of panicked warnings" and beseeched him to stay away from politics. Following these recollections the narrator says once again, "I woke up to find myself $(\mathrm{t})$ here." The section between the two occurrences of this sentence, a disjointed set of flashbacks, is therefore a sort of closed bubble, containing Furāt's recollections of three people who cared for him: 'Alī, Sarmad, and his grandmother.

It should be noted that in combining surreal dreams with reality-sometimes so seamlessly that it is difficult to discern which is which-Antoon exploits the literary technique of magical realism as a kind of ongoing dialectic between images and imagination, the natural and supernatural, and rationality and irrationality. ${ }^{13}$ This style of writing is chiefly a Latin American

13 Writers of prison literature often incorporate elements of magical realism in their works. For example, in 'Abd al-Raḥmān Munīf's novel East of the Mediterranean, Rağab, a former prisoner, escapes aboard a ship. His journey is described as follows: "The Aeschylus swings, shudders, moves away with a heavy movement like the dance of a slaughtered chicken." And in Șunallāh Ibrāhīm's That Smell, the nameless protagonist "returns to the [Cairo] metro, to wander around this societal labyrinth into a totally blurred future; he is indeed like the young man who ..., rowing in the Nile, loses an oar, and is swept along with no control over either direction or pace." See Elimelekh. Arabic Prison Literature. 137 and 139 .

Another Iraqi writer who employs magical realism in his works is Fāḍil al-'Azzāwi. Astrid Ottoson al-Bitar notes that in his novel al-Aslāf('The Forefathers') he uses magical realism to symbolically depict the complex situation in Iraq, a heterogeneous country living under a dictatorial regime (al-Bitar, Astrid Ottosson. "A Challenging of Boundaries: The Use of Magical Realist Techniques in Three Iraqi Novels of Exile". In: Borders and Beyond, Crossing and Transitions in Modern Arabic Literature. K. Easel and S. Guth (eds). Wiesbaden, Harrassowitz, 2011, 79. He also uses this technique in his novel al-Qal'ah alHāmisah ('The Fifth Castle'), first published in 1972, which appeared in English translation as Cell Block Five. 
narrative strategy that is characterized by the matter-of-fact inclusion of fantastic or mythical elements into seemingly realistic fiction. ${ }^{14}$ Amaryll Beatrice Chanady argues that magical realism, like fantasy, is a literary mode rather than a literary genre. In the 1940s, Central and South American authors used it as a means to express the authentic Latin American spirit and to develop an independent style. Its most salient characteristic is the presence of the supernatural and of elements that are at odds with our conventional view of reality. ${ }^{15}$ González Echevarría, quoted by Chanady, believes that magical realism offers a world view that is not based on natural or physical laws or on objective reality. Floyd Merrell, also quoted by Chanady, explains that magical realism stems from the conflict between two pictures of the world, the rational and the magical, and that it already exists in the works of Kafka and Proust. Chanady remarks that if magical realism combines a rational world with an irrational one, then Bulgakov's The Master and Margarita in which the Devil visits 2oth-century Moscow and Miguel Ángel Asturias' Men of Maize in which a man transforms himself into an animal can also be included in this category. She concludes that magical realism is characterized by "two conflicting but autonomously coherent perspectives: one based on an "enlightened" and rational view of reality and the other on the acceptance of the supernatural as part of everyday reality."16

Sanchez, Calve, and González write that "whereas realism depicts one possible 'horizontal' world that coincides with the tangible, the verisimilar, and the so-called 'objective,' magical realism presents a multifaceted and multilayered reality and history that allow a vertical perspective."17 D'haen writes that magi-

Ǧādah al-Sammān uses elements of this technique in her short story collection The Square Moon (al-Qamar al-Murabba ). In her article, Fadia Suyoufie, "Magical Realism in Ghādah al-Sammān's The Square Moon". Journal of Arabic Literature 40:2 (2009), 182-207, writes, "Through magical realism, [al-Sammān's] characters are transported to new territories of consciousness and, as readers, we are urged to have a more nuanced perception of reality. Viewing herself as a medium, al-Sammān summons diverse intertextual 'specters', which becomes a haunting experience for the reader" (p. 205).

The writings of the Libyan Ibrāhīm al-Kūnī, and especially the novel Nazîf al-Hağar, should also be considered examples of Arab magical realism. See Cook, Miriam. "Magical Realism in Libya". Journal of Arabic Literature 41:1-2 (2010), 9-21.

"Magical Realism," Encyclopedia Britannica <http://www.britannica.com/art/magicrealism $>$ (accessed 28 May 2016).

Chanady, Amaryll Beatrice. Magical Realism and the Fantastic. New York and London, Garland Publishing, 1985, 16-21.

16 Ibid., 16-21.

17 Benito Sanchez, Jesus; Manzanas Calve, Ana Ma; Simal González, Begonia. Uncertain Mirrors: Magical Realisms in US Ethnic Literatures. New York, Recopy, 2009, 51. 
cal realism aims to "create an alternative world correcting so-called existing reality, and thus to right the wrongs this 'reality' depends upon." Furthermore, "it is a way of access to the main body of 'Western' literature for authors not sharing in, or not writing from the perspective of, the privileged centers of this literature."18

According to William Spindler, magical realism exhibits three types: metaphysical, anthropological, and ontological. Metaphysical magical realism does not explicitly address the supernatural but merely imbues the familiar and known with a sense of eeriness and melancholy. The anthropological type combines the Western rational worldview with the supernatural perspective of a particular ethnic group, and the ontological variety presents the supernatural as a matter-of-fact part of everyday reality that does not conflict with logic and therefore requires no explanation. ${ }^{19}$

The novel I ğăm seems to employ mainly metaphysical magical realism for, while it does not describe supernatural occurrences as such, the surreal hallucinations that are incorporated into the text certainly lend the novel a sense of strangeness and uncanniness. Astrid Ottosson al-Bitar notes that many works by Iraqi authors in exile, both those that describe the exilic existence and those that describe the horrors of life under the Iraqi dictatorship, including works by Fādili al-'Azzāwī and Antoon Sinan, are characterized by such a sense of uncanniness. ${ }^{20}$ Their novels describe a surreal reality and even if the events portrayed in them are not implausible, they are imbued with a unique, almost supernatural air that blurs the boundaries between the real and the unreal. ${ }^{21}$

D'haen, L. Theo. "Magical Realism and Postmodernism: Decentering Privileged Centers”. In: Magical Realism: Theory, History, Community. Lois Parkinson Zamora and Wendy B. Faris (eds). Durham, N.C., Duke University Press, 1997, 194-195. Spindler, William. "Magic Realism: A Typology”. Forum for Modern Language Studies 39:1 (1993), 79-82. Techniques in Three Iraqi Novels of Exile". In: Borders and Beyond. 63-66.

21 This technique of magical realism is used to describe situations that are complex or exceptional, which also serves as a means of subversion and rebellion and as a show of strength on the part of the writers. In her article "Iraqi Short Fiction: The Unhomely at Home and Abroad," Ferial J. Ghazoul also uses the term "uncanniness" in describing the works of some Iraqi writers who she says "display artistically a variety of ways-from the simple to the sophisticated-of integrating the strange episodes verging at times on what Freud called Unheimlich, translated as 'uncanny' by the psychoanalytic professional Alix Strachey and more recently as 'unhomely' by the postcolonial critic Homi Bhabha." Ghazoul, Ferial J. "Iraqi Short Fiction: The Unhomely at Home and Abroad". Journal of Arabic Literature 35:1 "Iraqi Literature” (2004), 1-24. 
Wendy Faris observes that magical realist works are frequently written in response to tyrannical regimes; this, because magical realism often serves as a strategy to subvert and defy the established social order by challenging accepted definitions of time, place, and identity. ${ }^{22}$

In high school Furāt and his classmates were all signed-up members of the ruling party. But several years later when a fire broke out in the Student Union office and destroyed the registry of party members, Furāt took the opportunity to "return to the ranks of the independent." He did not re-register even when threatened that non-members would not be accepted to a master's program. As at many points in the novel, Furāt pointed out dryly that his threat stands in contradiction to the regime's slogan, "All good workers are sons of the revolution, and Ba'thists even if they do not join the party" (p. 43).

The novel is replete with scathingly bitter criticism of the Saddām Husayn regime that deified the leader and persecuted anyone who rejected or avoided his personality cult. Iraq under Ṣaddām Ḥusayn is described as a surreal world in which one could be punished for discarding a newspaper bearing a photo of the leader; or article about the leader giving a medal to a father who killed his son for refusing to join the army; or an item on a kindergarten teacher informing on a boy's father after the boy repeated an anti-regime joke he had heard at home; or for disregarding a compulsory call for students to skip classes in order to participate in marches and demonstrations of support for the regime. Furāt also relates the story of his friend Fallăh, a gifted artist who never held an exhibition because he refused to include a portrait of the leader in his portfolio ( $\mathrm{p}$. 11). Furāt himself writes poems and short stories but is unable to publish them. A newspaper rejected a story he wrote about a grief-stricken mother who waits for the body of her only son to return from the war, because the story was "useless for recruitment purposes." The editor told him that "the mother of a martyr should greet the body of her son with songs of joy" (p. 19). An interrogator in prison also condemns him because, instead of writing poetry supporting the war effort, he expressed "disdain for everything we hold sacred" (p. 30-31).

Another form of injustice that infuriates Furāt is the callous indifference of the regime's bureaucrats. Furāt describes a cartoon he saw in a newspaper, in which a government employee "sits behind a desk like an emperor, and in front of him stands a poor citizen, fatigued after a long day in search of signatures and stamps. The citizen, out of breath and dripping with sweat, needs just one more signature to complete his task, but the bureaucrat tells him, 'Come back 
tomorrow so I can tell you to come back tomorrow'" (p. 12-13). Men like Furāt, exempt from joining the army for medical reasons, also had to deal with the regime's exasperating bureaucracy. Applicants are made to wait for hours in an unroofed courtyard in the summer heat, without any benches to sit on, even the ill and the disabled.

The injustice and hypocrisy he witnesses prompted Furāt to rebel in many different ways. As one act of rebellion, he decides to write his thesis on Orwell's novel 1984. His first challenge is finding a copy. The chair of the English Department, Dr. Khalid, admits that he read the book on a visit abroad and given its content, he advises Furāt against writing a thesis on it, saying that it would get both of them into trouble. Professor Taariq, charged with supervising theses (who received his post by spying for the party), rejects the proposed topic, saying, "Who is this Orwell? Never heard of him" (p. 37).

Furāt also responds to the injustice and hypocrisy that he sees around him in another way-by withdrawing into his inner world. This happened, for example, at a rally he attended at college. Earlier that morning the media had announced a great military success, but the cars bearing the bodies of the dead that were beginning to arrive from the battlefront told a different story, revealing the extent of Iraqi losses. The casualties were ignored by the media, of course, and a banner hanging at the campus gates declared triumphantly and untruthfully: "The Soldiers of the Leader Compose Another Epic." Listening to a speech by the dean, whose post was conferred upon him for verses he composed praising the party, Furāt feels nauseated and begins to shut out the reality around him. He hears nothing but the applause following certain 'magical words' such as "leader" ... "party" ... "revolution." He refuses to join in the applause, even though he knows that informants are looking out for those who do not clap.

It is the constant persecution, hypocrisy, and horror that caused Furāt to withdraw into himself. The text reflects these alternates between realistic descriptions of his experiences and surroundings and the fantastic descriptions of his dreams and hallucinations, which are rooted in the same dark reality. Weaving together the narrator's external and internal worlds, the technique of magical realism creates a complex, vivid, and what may be considered a threedimensional picture of life under a totalitarian regime. In one of the fantastic sections of the novel, Furāt tries to find shelter in an inner silence but instead experiences a nightmare filled with horror and shrieking:

I dig in this silence, searching for a yet deeper silence to burrow into, but the screaming assaults me again. [...] Screams mingled with a mocking 
laughter. I am laughing too, and then I cry. I see a tall door in front of me stretching from the floor to the ceiling. I reach to open it. A long path appears, lined with trees in whose thick branches rustle all the letters of the alphabet. As I step onto the path, a storm wind blows. I hear a murmuring in the branches - the dots of the letters are falling from the trees like autumn leaves, and the letters are left as bare as branches. The letters fall too, each pronouncing its own sound as it strikes the ground. [...] The letters are changing color, from black to dark green, to light green. They begin to stir, spinning in spirals on the path. They are grasshoppers, turning and jumping. They spring into the trees. They are locusts. They bite hungrily into the branches. They swallow trees whole. The wind howls again, pushing me back inside. The door closes and fades away, but I can still hear the locusts ruining the silence (p. 19).

Like many of the fantastic scenes in the novel, this scene reflects the extreme violence of the regime and the terrible suffering it creates. The locusts that devour the branches represent the regime's rapacious policies. However, like the fantasy about the dancing letters described above, this one too also contains images of letters and writing. In fact, most of the fantastic scenes in the novel contain images of letters, paper, ink, or books and are thus related, first and foremost, to the act of writing and to the pain and danger it can incur under a totalitarian regime. For a dissident author, writing can lead to imprisonment, torture, and even death. However, refraining from writing-or writing according to the dictates of the regime-is equally painful for a freedom-loving and creative mind. This creates a paradoxical situation in which the writer is trapped, facing anguish no matter which option he chooses. The recurring mention of bars, barbed wire, walls, and of being pursued and hunted underscores this sense of persecution and of being trapped, both physically and mentally.

In a dream that very poignantly reflects the author's dread of being persecuted for his writing, Furāt sees himself lying on white sand, as rain "the color of ink" falls. He hears cars and barking dogs approaching and begins to run. Looking behind him, he sees his "footsteps writ clearly on the white sand." Men with flashlights pursue him as he runs between the "bars of light." He falls into the mud and crawls "like an animal" trying to escape. Waking up from this dream, he asks himself, "Do I write?"

These stream of consciousness depictions of dreams or hallucinations often contrast sharply in tone with the sections that immediately precede them. For example, a gentle description of 'Arĭğ, the girl Furāt loves, is followed by this nightmarish segment: 
Unraveling from the whiteness of the page, suns emerge tearing through the darkness of this night, recalling another galaxy. But they are captive suns, these others, trapped behind bar after bar, as if these lines were cords, or barbed wire upon which the words perch like frightened birds stalked by hunters or an approaching warden (p. 50).

Then Furāt awakes from this nightmare. "I woke up to find myself (t)here." But the next segment seems more like a continuation of his surreal dream. He sees himself crouching in front of a wall. Hearing groans from the other side, he begins to dig into the wall until he manages to make a hole in it. But he succeeds only in digging his way into a "neighboring nightmare" that mirrors the one he was in. "I saw myself, crouched in front of a vast wall, holding my ear against it" (p. 50-51). In fact, at many points in the novel, the mention of waking up is followed by a segment that sounds more like a nightmare, so that the boundary between dreaming and waking, reality and fantasy, is blurred. This underscores the sense that under a dictatorial regime even waking life is often like an endless and absurd nightmare from which the citizens cannot escape.

Ultimately, the terror of the regime, which sows fear and anxiety in the citizens to the point of undermining their mental health seems to affect even nature itself. In Furāt's nightmares, nature undergoes a frightening transformation: clouds become red, rain becomes black, and the sun surrenders.

The horror in the novel comes to a head in the descriptions of the sexual abuse Furāt suffers in prison, at the hands of one of the guards, abuse that almost causes him to lose his mind:

I can feel his sticky fingers on my right thigh as he holds me down. His dirty fingernails dig into my skin. I close my eyes and try to disappear from existence, to flee my body, to abandon it forever ... Aah, if only I could shed it, exchange it for another form [...] Many small things shattered inside of me every time, things I can't name or identify [...] Perhaps they have won, with all this filth they've smeared on the walls of my memory and subconscious - their slogans that reek of piss, the shit that piles up in the abandoned streets of my body. How can I be rid of it without dying myself, or going mad?23 (p. 21-22)

23 Ahmad. Adab al-suğūn. 252, writes that Furāt's wish to "exchange [his body] for another form" is reminiscent of the transformation that Gregor Samsa undergoes in Kafka's Metamorphosis". 
In this novel Antoon uses and manipulates language to show that reality is multilayered and riddled with contradictions. To this end he alternates between "repulsive realism" 24 and inspired lyrical passages, like the one quoted above: "... as if these lines were cords or barbed wire upon which the words perch like frightened birds stalked by hunters or an approaching warden" ( $\mathrm{p}$. 50 ). Laila Lalami writes that the recurring motif of the "dotless" text "calls upon us to exercise our freedom in interpreting it and to discover its hidden meanings" and concludes that such a situation "requires one to bear witness through any medium available."25

To conclude, Milich writes that I I $^{\prime} \bar{a} m$ is a prominent example of a postcolonial Arabic novel that combines postmodern writing techniques with a 'new humanist' orientation inspired by 2oth-century German and French philosophy and by intellectuals like Edward Said and Elias Khoury, and further shaped by the social and political crises of modern Arab societies. Alongside realistic descriptions, the novel exposes the protagonist Furāt's internal reality, a convoluted world dominated by hallucinations, nightmares, and memories of the past. The novel contains many surreal scenes (strange and painful nightmares) and can therefore be seen as a Kafkaesque work that presents a destroyed and ruined reality - a world of absurdity and uncertainty ruled by demonic, depraved, and arbitrary forces. For Antoon, the dictatorship of the Iraqi regime is expressed best by casting it in a mirror-like Kafkaesque reality. ${ }^{26}$

Yã Maryam (Hail Mary) ${ }^{27}$ from 2012 tells the story of another Assyrian Christian family living in Baghdad. Though the novel frequently looks back to

24 The term "repulsive realism" is introduced by Saad A. Akbazei's revies of Ijaam: An Iraqi Rhapsody. In: World Literature Today 82:6 (Nov-Dec. 2008), 58.

25 Lalami. "The Dot Matrix". 36.

26 Milich. "Conceptions and Representations". 174-178. Another author whose works feature Kafkaesque magical realism of this sort is Bruno Schultz (1892-1942). His stories are a startling combination of reality and fantasy and as in Kafka's works the main character is usually a father figure whose business is failing and who gradually loses his mind. On Kafka's influence Arabic-language literature, see also Elimelekh, Geula. "Fantasy as 'Recovery, Escape and Consolation' in the Short Stories of Isaac Bar Moshe". Middle Eastern Studies 50:3 (August 2014), 426-441 and "Samīr Naqqāsh: Between the Sacred and the Demonic". Studia Orientalia Electronica 3 (2015), file://D:/User/Downloads/46228-39117-1-PB.pdf (accessed 17 November 2016).

Antoon, Sinan. Yā Maryam. Beirut, Manšurāt al-Ǧamal, 2012. This work has now been translated into English as The Baghdad Eucharist (Cairo and New York, Hoopoe, 2017). 
the Șaddām Ḥusayn era, it takes place in the period following the American invasion of 2003 - an invasion which not only failed to end the country's raging, internal fighting but rather exacerbated it, plunging Iraqis into an even deeper and more difficult crisis. In this novel Antoon focuses on the persecution, discrimination, and displacement suffered by the nation's ethnic minorities, whose members are considered alien and "other," a foreign enemy that must be eradicated by any means often involving extreme brutality. ${ }^{28}$

The first part of the novel centers around an old man named Yūsuf and the second around his relative, a young woman named Māhā. She and her husband find shelter in Yūsuf's large house after having been violently driven out of their home in Baghdad's al-Dura neighborhood. Lodging in the home of a relative, Māhā is a refugee in her own city. She represents the younger generation, which is the complete opposite of the older generation to which Yüsuf belongs.

Yūsuf, a man in his eighties, witnessed the many changes and upheavals in Iraq since the 1930 s and managed to survive by leading a simple life. After two disappointing love affairs that did not lead to marriage, he decided to remain single. He shared his home-which he built himself-with his pious sister Hanna, who led an ascetic existence, devoted her life to helping the needy andafter her death, he continued to live there alone. He recalls that he and his friends used to meet at the local public house but in 1994, following the end of the Iran-Iraq War (1980-1988) the authorities shut down the pub so the group transferred its meetings to Yūsuf's home. Yüsuf also relates that the authorities shut down for "security reasons" the Chaldean church where he prayed, thus forcing him to attend prayers at an Armenian church. He says, "Ultimately, the important thing is that all prayers reach God, regardless of language and religious school" (p. 13).

28 Ibrāhīm Sacd al-Dīn notes that in 1995 Arabs constituted only 8 percent of the world's population, yet in the fifty years between 1945 and 1995, the Arab world was responsible for 25 percent of the world's ethnically motivated armed conflicts, costing the lives of 2.5 million people. In 2012 the peoples of the Middle East constituted only 6 percent of the world's population, yet the religious, sectarian, and ethnic conflicts in the region continue and the number of victims has apparently doubled. Iraq is one of the countries that clearly reflect these internecine tensions. Until the fall of Șaddām Ḥusayn, the Sunni minority held the reins of power in the country. Today, this minority is unwilling to accept the rule of the Shiite majority despite the elections that were held there. Especially at risk are the Christians, whose plight, dire under Șaddām Ḥusayn, is even more woeful today, for they are targeted by al-Qaeda and IsIs terrorism. According to reports, some 2,00o Christians have been murderedsince the demise Saddam Hussein in 2006, precipitating a wave of Christian emigration to the West. goo.gl/5TBgHA (accessed 7 November 2016, Hebrew site). 
The circumstances of Yūsuf's and Māhā's lives reflect the plight of the minorities in Iraq and the divided nature of Iraqi society. Ghazoul emphasizes the importance that Iraqis, even Iraqis in exile, ascribe to the unity of their society and the territorial integrity of their country.

Non-Iraqi commentators may propose a divided Iraq and claim its lack of viability as a unified country, but the literary and artistic discourse-in its popular and elite manifestations - among Iraqis in Iraq or in the diaspora belies such tendencies. Even when Iraqis are away from their first sky-to borrow the expression of the Iraqi poet Sa'dī Yūsuf - they remain attached to their country of origin. When an Iraqi artist like Ardash Kakafian — of an Armenian background-died in France, he asked specifically to have his ashes deposited in the Tigris, so he would return to the land between two rivers of his childhood and youth. This is by no means extraordinary: being away does not mean severing identity or dismissing the past. We live in a de-territorialized world but diasporan Iraqis cannot imagine themselves without Iraq, just as diasporan Irish cannot imagine themselves without Ireland. ${ }^{29}$

Antoon describes the natural desire of Iraqis to live in coexistence and peace. This desire is reflected in Yūsuf's warm relationship with his Muslim friend Sa'dun, who comes to the funeral of Yūsuf's sister Hanna, helps with her burial, and reads the fätihah over her grave-just as he did at the funerals of Yūsuf's brother Mihāìil and his other sister Ḥabībah. In his youth Yūsuf also had a Jewish friend, Nissim whose family was forced to leave the country for Israel in $195^{1}$ after Nissim's father was fired from his job and their assets were seized.

The two main characters in the story have a different outlook on the presentday situation in Iraq and its future. Alarmed and discouraged by the violence and by the prosecution of minorities, Māhā is deeply pessimistic. She points out that Christians are being murdered and churches are being torched all over Iraq and also a similar situation exists elsewhere in the region, for instance in Egypt, where Copts are attacked and branded as "infidels." "The Muslims want the country all to themselves," she says (p. 26).

Yūsuf, however, is more optimistic. As an old man who has lived in Iraq for many decades, he remembers times of peace and coexistence, and hopes for their return. He is also deeply aware of Iraq's long history and especially of the Christians' long-standing presence in the country, which predates the Muslim presence by many centuries. "The museums are full of evidence of this. We have been here from the beginning," he says. "If this isn't our country, I don't know whose it is!" (p. 26). Having a profound sense of his roots in Iraq, Yūsuf

Ghazoul. "Literature and the Arts". 234. 
refuses to leave Baghdad, whereas Māhā wants to leave the country the minute she finishes her studies in the faculty of medicine. Yūsuf explains that her impatience and her bleak outlook are understandable, since throughout her life, she has experienced nothing but war, and so he says,

I must forgive her. Her times are not my times. Her youth is not my youth. From the moment she first opened her green eyes she has seen wars and siege. She tasted deprivation, hunger, killing and displacement from an early age. But me, I have seen good times that I still remember and in which I still believe (p. 11).

Yūsuf finds solace not only in his memories but also in his garden, which is a source of pleasure amid the bleak reality that surrounds him. Yūsuf draws a direct connection between his memories and the garden, saying, "Perhaps the past is like my garden, which I love and care for as though it was my home" (p. 11). He is especially fond of his palm tree, for he knows that these trees were an important part of Iraq's historical heritage. Reading about ancient Mesopotamia, he learned that this tree was revered and even sanctified, and that images of palms were carved on the walls of temples and adorned the thrones and crowns of Sumerian and Babylonian kings. In Yūsuf's mind the palm tree symbolizes his roots in Iraq and his entire life, as he says, "How great the similarity between a man and a palm tree [...] Just as the palm tree is not just a tree, but an entire life rooted in the soil beneath, the sky and the air, so a house is not just bricks and mortar, but an entire life" (p. 85).

The palm is also connected to Iraq's more recent history, because the Șaddām regime, which focused on the oil industry, destroyed many date palm plantations, forcing villagers to migrate to the cities. Their plight was exacerbated by the wars, which "behead both men and trees" (p. 84). ${ }^{30}$ The novel reflects on

3o Trees as a symbol for attachment to one's home and country also appear in other Arabic literature dealing with emigration and exile. Two examples are the novels The Trees and the Murder of Marzūq and Cities of Salt by 'Abd al-Raḥmān Munīf, which are stories of displacement that lament the loss of traditional lifestyle and culture. In the first of these works a villager is forced to uproot his fruit orchard under the pressure of fellow villagers, and in the second peasants are uprooted and forced to leave their homes to make way for oil fields.

The tree as a symbol of nostalgia for the motherland also appears in Palestinian literature. For example, in her poem "The Deluge and the Tree", Palestinian poet Fadwà Tūqān states that the Tree, symbolizing the land of Palestine and the Palestinians, has not been destroyed. Though many Palestinians live in exile, Palestinian history shows that Palestinians are too deeply rooted in their land to ever be removed from it, she asserts. 
how the indifference and cruelty of men destroy the beauty and wonder of the natural world, just as they destroy the cultural, religious, and family heritage of indigenous ethnic groups such as the Chaldeans. Yūsuf finds it difficult to cope with this reality and does not understand it. He is constantly preoccupied with a fundamental conundrum: "the question of all this cruelty that God allows without punishing its perpetrators" (p. 98).

Like $I \check{g} \bar{a} m$, this novel also deals with the theme of historical documentation of a different but no less important kind. In I'g $\bar{a} m$ the documents are Furāt's diary and the accompanying General Security memo, while in Yã Maryam this aspect is embodied by etched reliefs and writing in stone and other archeological artifacts providing tangible evidence of the past, which for Yūsuf carry forward Iraq's rich heritage and the Christians' deep roots in this land. Another aspect of this theme is Yūsuf's old family photos, which remind him of better days when his relatives were still alive and united in a time when Iraq's future was more hopeful. Much of the first part of the novel is devoted to Yùsuf's reminisces of his closely knit and highly educated family, which are evoked as he leafs through his photos. One of these shows Yūsuf's father dressed in traditional clothes that reflect his pious character. Looking at the albums was always a source of comfort for him. The images, however, also record the family's gradual disintegration, which parallels the national breakdown into internecine conflict and war.

The disintegration began in the 199os, after Șaddām's invasion of Kuwait, as many family members emigrated and others died in strange and tragic ways. The first victim was Yūsuf's brother Miḩa'îl, who became deeply depressed after the authorities canceled a promising agricultural project that was very close to his heart. Miha'îl lost his purpose in life and eventually died poetically of a heart attack. Yūsuf's sister Habībah became ill with cancer and died 18 months later. Another brother, Elias, was imprisoned and severely tortured for his communist leanings. He was released in 1999, but the torture took its toll on his psyche and memory. One day he left home and did not return; a week

In his short story "The Land of Sad Oranges" and in other stories and novels, Ġassān Kanafānī articulates the symbolic significance of the orange tree as a direct reflection of the loss of and exile from the land left behind. He used this symbol to communicate a living connection between the land of Palestine and its exiled population and to depict Palestinian resistance to its occupation. He formulated a new consciousness aimed at motivating revolutionary action and social organization to put an end to the people's continued refugee status. See Abū Farḥah, Nāṣir. "Land of Symbols: Cactus, Poppies, Orange and Olive Trees in Palestine," Identities 15:3 (2008), http://www.tand fonline.com/doi/full /10.1080/10702890802073274?src=recsys(accessed April 27, 2017). 
later he was found dead. In 2003 the remaining brothers and sisters began emigrating to Canada, Sweden, and New Zealand, leaving only Yūsuf and Ḥanna in Iraq.

Amid this reality, another source of comfort for Yūsuf is the world of music and poetry. While his brothers and sisters fled Iraq by emigrating to other countries, he escapes into himself by listening to music. "Songs, and especially maqāmas, ${ }^{31}$ were the chambers of my soul which I would enter to sit there alone" (p. 93).

The second part of the novel focuses on Māhā, who was born in a bomb shelter where her family was taking refuge during the 1990-1991 Gulf War. By this stage of the story, most of her close relatives have emigrated to Europe, America, or Lebanon, while others chose exile within Iraq and moved to Mosul or Irbil. It bears repeating that her entire life has been lived in the shadow of violent events like the kidnapping and murder of her uncle, probably due to his Christian identity.

As mentioned above, Māhā is compelled to move into Yūsuf's house after a bomb exploded outside her home in al-Dura, causing her to lose the baby she was carrying. The trauma and the miscarriage inflict an indelible wound that plunges her into deep depression.

The story reaches its climax when Yūsuf and Māhā are attending prayers at their church one Sunday and a group of terrorists enter the sanctuary and begin slaughtering the members of the congregation. (A note at the end of the novel explains that though Yūsuf and Māhā are fictional characters, this is a reference to a real event - the $3_{1}$ October 2010 attack by six suicide bombers armed with rifles and explosive belts on the Lady of Salvation Church in Baghdad, in which dozens of worshippers were massacred during evening Mass). Yūsuf is hit by a bullet andis gravely wounded. Just before he dies he murmurs, "Yã Maryam" (Hail Mary). Māhā is held hostage along with other worshippers, but ultimately escapes with her life. After her release she gives an interview on Iraqi television, in which she voices the Christians' pain and outrage and in conveying their tragedy to the Iraqi people and to the world at large, she says:

Maqām "is the principal melodic concept in Middle Eastern musical thought and practice [...] Each performance of Arabic classical music is said to be cast in a maqām, whose attributes are a scale consisting of a collection of tones, characteristic motifs to which an improviser or composer consistently returns, and a distinct character perceived by the informed listener." https://www.britannica.com/art/maqam-music (accessed 17 November 2016). 
We are being targeted. Are they trying to drive us out of the country? We are accused of being infidels and of collaborating with the occupation forces, and so on. These are all lies and a distortion of history. [...] Nobody supports us, neither Iran, nor Saudi Arabia, nor America. America has not helped us. On the contrary, our situation has gotten worse. Ultimately we have nothing but God and our faith. We did not come from outside Iraq. We have been here for centuries. Let people hear. History attests to this and the archeological evidence attests to this. Our monasteries and [archeological] sites are here, and not only in the north. All over Iraq. Even in Najaf, Karbalā' and Nāșiriyyah there are churches and monasteries. We do not seek to take over the reins of power. We have not robbed, murdered or burned. All we want is to live in peace. Our religion is a religion of peace (p. 155).

Like I $\check{g} \bar{a} \bar{m}$, this novel exhibits various forms of magical realism, for the characters experience strange dreams and nightmares that blend into their dayto-day reality. Yüsuf dreams that he has gone bald and his home has become a museum. He sees tourists entering, led by a guide who gives them misguided information about the house. Yūsuf approaches and cries out, "This is my home and I am the guide here." But nobody hears him (p. 12). This dream repeats the novel's theme of recording and documenting, also present in I'ğăm. It reiterates Antoon's observation regarding the difficulty of keeping an accurate or objective record of the past, and especially of documenting the crimes of dictatorial regimes that conceal, destroy, and distort historical evidence. In this dream the museum, meant to preserve culture and provide a faithful record of the past, instead provides a distorted picture of culture and history, because the telling of the narrative has fallen to strangers. Like Furāt's undotted manuscript open to misunderstanding, the museum in the absence of a qualified guide becomes vulnerable to misinterpretation and misrepresentation.

The novel presents a conflict between two generations and between present reality and memories of the past. Its optimism, however, lies in its remembrance of Iraq's glorious ancient history as well times in its more recent past when peace and coexistence prevailed. Yūsuf, an Iraqi faithful to his homeland, survives (until his untimely death) thanks to his memories and his hope that the civil war may someday end, for he believes that the internal tensions in Iraq stem from dictatorship and war and from the struggles among powerhungry politicians, rather than from inherent hostility between the religious communities. 
In his article "The Shī‘ah in Iraqi Novels," Ronen Zeidel writes that throughout the 2oth century, Iraqi literature avoided any expression of the distinct Shiite identity, since such expression was considered "sectarianism" and was strictly condemned. However, since the 1990s changes occurred against the background of the Shiite Intifada of March 1991 and its exceedingly savage repression, the rising violence generally in Iraq, the weakening of the (Sunni) regime, as well as the dispersion of Iraqi literary circles away from Baghdad, and the ascendance of a new generation of exilic writers. As a result novels began to appear that were either Shiite in their religious persuasion or advocated the integration of the Shiite tradition into a secular atmosphere. ${ }^{32}$

Antoon's 2012 novel Wahdahā šağarat al-rummān (The Pomegranate Alone), ${ }^{33}$ translated into English by the author under the title The Corpse Washer (2013), ${ }^{34}$ depicts Iraqi Shiites and their unique identity. Its literary view of Iraq's reality is much darker than Antoon's other books because death is a major theme. The narrator, Ğawwād Kāẓim, belongs to a Baghdadi Shiite family whose livelihood for generations has been the preparation of the dead for Muslim burial. Death accompanies Ğawwād wherever he goes and at every moment. "Death is not content with what it takes from me in my waking hours, it insists on haunting me even in my sleep" he says (p. 3).

In high school Ğawwād developed an interest in the fine arts thanks to Rāiid Ismāîl, his excellent teacher who taught the students that art has been depicting life since the dawn of time and that everything in the world is crying out, "Paint me!" Art, he said, is the mirror of life and also a way to give permanence to the mortal and the transient (p. 30-31). Antoon and his characters cleave to art in as much as it is means to overcoming death and achieving a form of immortality. Ismāîl also imbues his students with a sense of Iraq's great contribution to human civilization and culture, stressing that writing was invented there and the world's most ancient temples are found there. "We all were inheritors of this great treasure of civilization that enriches our present and future," says Ğawwād (p. 31).

32 Zeidel, Ronen. "The Shī'ah in Iraqi Novels", Die Welt des Islams 51: 3-4 (2011), 327-357.

33 Antoon, Sinan. Waḥdahā šağarat al-rummān. Beirut, al-Mu’assasah al-'arabiyyah li-ldirāsāt wa-l-našr, 2010.

34 Antoon, Sinan (trans.). The Corpse Washer. New Haven and London, Yale University Press, 2013. All quotations in this paper are from this translation, unless otherwise stated. 
Ğawwād begins his studies at the academy of fine arts just as the Iran-Iraq War breaks out. His teacher, 'Ișām al-Ğanabī, a world-renowned sculptor, is a formative influence on him and deepens his love and his commitment to art. Ğawwād's father, on the other hand, objects to his studies because he believes they will not equip him with practical skills. He believes that his own profession as a corpse washer is more respectable and useful to society, but Ğawwād has no intention of continuing in the family tradition by learning his father's skills.

Like Antoon's other novels, The Corpse Washer depicts life in the shadow of unending upheaval: the eight-year long Iran-Iraq War, which is soon followed by the 1991 Gulf War and later the 2003 American invasion. Ğawwād says that "Baghdad, which had been one big open-air prison, became a series of prisons side by side, guarded by the militias. One jailor embraced another within the tall cement walls" (p. 88 in the Arabic novel ${ }^{35}$ ). The constant turmoil eventually takes the life of Ğawwād 's father, who dies of a heart attack while bent down in prayer during one of the bombings in 2003. Like Yūsuf's father in $Y \bar{a}$ Maryam, he is a serious and devout figure, the embodiment of tradition and piety. After his death Ğawwād is filled with regret that he did not know his father better and because he refused to follow him into the family profession, of which he was ashamed.

This sentence does not appear in the English version of the book. In his article "Necropolis," Sinan Antoon not only refers to Baghdad as a big prison, but also adds, "It is a vast grave [...] Wherever I lean, I hear the same echo: death's pulse crawling on distant walls, on which Iraqis lean as they gaze into an abyss. They listen to the pulse of death crawling in old bones. And new ones [...] Baghdad is a broken icon, buried in a fertile memory. Engravings on walls, tablets, body parts in books, debris in manuscripts, all carried by the doves and crows of reading. Poems, slogans, wars, invasions, and skulls laughing in nightmares addicted to the night. A night raised by spears and swords, then passed on to missiles and satellites as they monitor the ghosts dancing in and around Baghdad." See Antoon, Sinan. "Necropolis". Qui Parle 16:2 (Spring/Summer 2007), 1-3.

Apparently, Antoon was inspired by Achille Mbembe' article "Necropolitics," which asserts, "To exercise sovereignty is to exercise control over mortality and to define life as the deployment and manifestation of power." Antoon is not alone in this. Other Iraqi writers whose writings deal with death and tyranny also echo Mbembe, in particular his statement: "I have put forward the notion of necropolitics and necropower to account for the various ways in which, in our contemporary world, weapons are deployed in the interest of maximum destruction of persons and the creation of death-worlds, new and unique forms of social existence in which vast populations are subjected to conditions of life conferring upon them the status of living dead." See Mbembe, Achille. "Necropolitics". Libby Meintjes (trans.). Public Culture 15:1 (Winter 2003): 11-40. 
All three novels discussed in this paper juxtapose the cruelty and violence of some men with the sincere piety of pure-hearted individuals: Ğawwād's father in The Corpse Washer, Yūsuf's father and sister Hanna in Yã Maryam, and Furāt's grandmother in I'ğām. Antoon's message is clear: one's particular religion does not matter, for virtue is found in all faiths, and suffering too is shared by all.

The Corpse Washer presents the beauty of art and the wonder of the living, natural world as the antithesis of brutality and death. But at the same time it creates a perfect synthesis of life and death, showing that they are inextricably interwoven and one cannot exist without the other. This is represented by the father's profession, where death paradoxically sustains the family's livelihood; the pomegranate tree of the novel's Arabic title symbolizes this symbiotic relationship with even greater poignancy. The tree grows in the graveyard next to the canal into which the water from the cleansing of the corpses flows. Ğawwād's father loves the tree and tells his son that the Prophet Muhammad said, "There is a seed from Paradise in every pomegranate fruit" (p. 183). Ğawwād, however, refuses to eat from the tree after he discovers that it "drinks" from the waters of the canal. Only years later does he come to feel that his rejection of his father and all he represented was a mistake, for death must be embraced along with life.

The pomegranate tree embodies this interdependence between life and death, for the water that washes the corpses gives it life and fills its bloodred seeds. Moreover, in Shiite tradition and Muslim tradition in general, the pomegranate is associated with the afterlife. As part of a Shiite custom, its branches are placed next to the bodies of the dead to protect them from the "tortures of the grave." It is also mentioned in the Quraan (along with the palm tree) as one of the trees that grows in Paradise: "In both of them are fruits and date palms and pomegranates" (Qurān: Lv:68). ${ }^{36}$ In the last paragraph of the novel, Ğawwād says, "The living die or depart, and the dead always come. I had thought that life and death were two separate worlds with clearly marked boundaries. But now I know they are conjoined, sculpting each other. My father knew that and the pomegranate tree knows it as well" (p. 184).

$3^{6}$ Several ahādith about this verse and the Qurānic context itself indicate that the verse refers to paradise. Exegetes have explained that the phrase "both of them" in this verse refers to two gardens in paradise, one reserved for virtuous men and the other for virtuous ğinns (spirits). The Medieval Quranic exegete Ismā'īl ibn Katīir wrote in reference to this verse that the date palm and the pomegranate tree were singled out because of their virtue (Ibn Katīir. Tafsīr al Qur'ān al-Karīm. Sāmīi ibn Muhạmmad Salāmah (ed.). al-Riyāạ, Dār Țibah, n.d. Vol. 7, 507. 
Like the two previous novels, this one employs some aspects of magical realism, such as the seamless incorporation of dreams and nightmares into the text. In an apparent dream (apparent in that the author does not call it a dream) Ğawwād finds himself in the graveyard. The slab on which his father used to place the bodies for washing is very long. "It extends for tens of meters and has a white conveyor belt. Bodies are stacked on it. The belt moves toward the right and leads to a huge opening, and outside men wearing blue overalls and white gloves carry the bodies and throw them into a huge truck" (p. 75). In all three novels dreams and nightmares form an important element, which illustrates and underscores the characters' inner anxieties and dreads.

\section{$4 \quad$ Conclusion}

In his article "Postwar Iraqi Literature: Agonies of Rebirth," Salih J. Altoma notes that many Iraqi writers did not disassociate themselves from reality but saw it as their duty to keep writing, even if this meant living in exile. ${ }^{37}$ Altoma also argues that, starting in the 1950s, Iraqi literature was marked by "an increasing tendency towards universal themes and vision."38 This is true of Antoon's works as well, for they deal not only with what is happening in Iraq but with a more universal issue, namely, the devastating effects of hatred, division, and lust for power on human societies at large.

Antoon's three novels indeed demonstrate that Iraqi writers do not focus only on the grim reality - the chaos and the anarchy prevailing in Iraq-but also see beyond these to the nation's spirit and soul, and so they recognize that goodness and beauty still exist in the world. Ferial J. Ghazoul writes, "To overlook what is being produced in war-torn Iraq and to dismiss its poetry, fiction, art, music and cinema is to ignore what continues to be the soul of Iraq and to see only the wounded body of a country."39

An important message in the novels is that religious faith in itself is not harmful, though there are those who use it to do harm, such as the terrorists who murder innocents in cold blood while screaming, "Allāh akbar." They are contrasted with the characters who possess a pure and innocent faith which motivates them to do good, such as Yūsuf's sister Ḥanna and Ğawwād's father,

Altoma, Salih J. "Postwar Iraqi Literature: Agonies of Rebirth”. Books Abroad 46:2 (Spring 1972), 211-212.

38 Altoma. "Postwar Iraqi Literature". 217.

39 Ghazoul. "Literature and the Arts". 233. 
who dedicates his life to washing the deceased and in so doing sees this not as a degrading occupation but as a sacred task that brings him closer to God.

Antoon's postcolonial and postmodern works address these themes by applying the illusory subliminal stimuli of magical realism, which blurs the boundary between reality and fantasy, depicting reality through a series of surreal nightmares that emerge from the protagonists' memories and subconscious even as they reflect external situations and events. Magical realism mixes domains in order to challenge social boundaries that distinguish between identities, and between the self and the other-a motif that also recurs in literature dealing with exile and seeks to describe life in exile or life under an oppressive regime in surprising and unusual ways which are a revolt against truths and hierarchies that are ostensibly unassailable. 